\title{
Investigating the Effect of Store Image on Purchase Intention with Mediating Role of Service Quality: A Study of Hyper Star and Metro
}

\author{
Yusra Shakeel ${ }^{1} \&$ Sobia Sultana*2 \\ ${ }^{1,2}$ Lahore College for Women University, Lahore, Pakistan
}

\begin{abstract}
The paper aims at identifying the effects of store image on purchase intention in international retail outlets in Lahore, Pakistan. The study focuses on the different dimensions of store image that effect consumer purchase intention in the retail outlets and how service quality contributes in building store image significantly. A sample of 265 consumers was taken; the research is quantitative in nature. A questionnaire (survey) method was used and data were collected from two supermarkets Metro and Hyper star in Lahore. This development is an important focus for both researchers and operators of hypermarkets. EFA and CFA models are employed for the study. The study focuses on the importance of store image in retailing and how it influences purchase intention in a positive way. Service quality also contributes to store image and helps create customer satisfaction and loyalty which in return affect consumer perceived behavior. The results indicate that store image has a significant effect on service quality and purchase intention. Managers can make the perception of stores better by enhancing the service provided to customers. The management staff can improve the quality of interaction between the staff and the customers. The store environment can be improved and made more attractive to attract customers.

Keywords: store image, purchase intention, service quality, retailing.
\end{abstract}

\section{Introduction}

There has been a change in the consumers lifestyle, with changes in the demand of goods and services. It is evident that markets now stock global brands with consumer awareness, new technological inventions have made retailing more captivating and the demand for perfection from consumers has led to improved product quality. A change has been noticed in the retailing pattern and layout, the retailing channels now evolve around branded stores to meet the new demands of consumers (Jaliawala et al., 2014). The change in the retailing sector was more evident in the Western countries previously with the international retail chains like Wal-mart, Carrefour and Tesco. In context of retailing in Pakistan, the first entry was made by Metro and Makro in 2007 and later in 2009 Hyperstar was launched in major cities like Lahore, Islamabad and Karachi. Customers in Pakistan were used to shopping from traditional grocery stores when channel diversity in retail chains was less popular. A shift has been observed from the traditional stores to the branded international chain stores, since customers have evaluated the new retail chains in terms of product variety, convenience and the benefit of one-stop shopping. The importance of these large retail stores is evident from the customer spending at a particular store (Batislam and

*Corresponding author.

Email: sobia.hassan@lcwu.edu.pk
Filiztekin, 2011).

There has been considerable growth in the retailing business which is evident from the entry of multinational organizations which have expanded their operations in the developing and developed countries (Yaprak, 2008). Since the retail expansion is across cultures there is a difference in the perception of products and the way in which the products and services are perceived in terms of quality. Hence, the retailing business has become more bicultural and demanding (Zhang, 2009). The customer attitudes and expectations are different across countries and so the retailing business has been shaped according to the national boundaries in different countries (Davis et al., 2008). In eastern cultures the concept of browse and bargain is more evident than in western cultures where the prices marked are stated and fixed (Verhoef et al., 2009). A lot research has been conducted in retail shopping experience in the western culture while few are found in the Eastern culture (Arnould and Thompson, 2005).

In Pakistan, the concept of retailing has been modified with the new phenomena of self-service stores which were the kiryana stores located in small vicinities of the city. The self-service stores are usually associated with huge retail stores with wide variety of goods and ample place to shop and enjoy the shopping experience while some consumers still believe in the 
small retail stores with individual attention from the sales person. These small stores usually are the grocery stores while the entry of Hyper tsar and Metro has made it convenient for customers to do one-stop shopping.

\section{Literature Review}

\subsection{Store Image}

Store image is defined as the overall impact of perceived image associated with the store in the minds of consumers (Hartman and Spiro, 2005). It is also the symbolic association in the minds of the customers with perceived functions relating to specific stores (Šalčiuvienè et al., 2009). Store image is built according to the strategic positioning of the store in the minds of consumers (Dolbec and Chebat, 2013). Studies reveal that store image reduces risk, helps customers in major purchase decisions (Bao et al., 2011; González et al., 2007).

It is very important for the retailers to develop a clear store image in the minds of consumers since there has been drastic change in the behavior of consumers. Store image has gained considerable attention by academicians and practitioners. Prior research on store image has explained a direct relationship with purchase intention, also applicable in case of private store brands. It has been stated the more concrete the store image, the greater will be the chances of purchase by consumers (Collins-Dodd and Lindley, 2003; Diallo, 2012).

Priporas (2002) stated that store image was the most dynamic variable in the retail markets of Greece. The major store attributes are location, convenience, merchandize, design elements and store personnel behavior (Kaul, 2005). The Pakistani consumers need an extensive assortment variety and quality products under one roof (Moazzam and Badar, 2006). There are four types of shoppers identified which include typical, occasional, social and anti-social. These shoppers preferred store convenience, pricing ,products, merchandize and personnel, these factors also derive consumer satisfaction (Theodoridis and Chatzipanagiotou, 2009). Consumer satisfaction has been determined via store image and customer sale staff relationship (Bloemer et al., 2002). Mohan et al. (2013) has also explored the service quality dimension like shopping convenience, store environment, pricing \& promotion, responsiveness, customer sales service and billing.

\subsection{Cue Utilization Theory and Store Im- age}

When a brand is not popular among customers, they estimate the value of a brand from the image of the retail store (Vahie and Paswan, 2006). The reason being that customers can associate the private label brand with the store itself. The product assortment of a retail store represents the quality and variety of brands carried by the retail store. Store image can be used as an extrinsic cue to judge the value of a brand (Ailawadi and Keller, 2004; Collins-Dodd and Lindley, 2003). A positive store image creates a positive brand image (Dhar and Hoch, 1997; Pettijohn et al., 1992). Store image can thus influence the judgment for a brand. The way in which consumers arrive at quality judgments is called cue utilization theory (Sprott and Shimp, 2004). It includes extrinsic cues which do not affect products appearance (brand name, store name and price) while intrinsic cues relate to core product characteristics like (texture, ingredients, taste and smell) (Herz and Diamantopoulos, 2013; Woodside, 2012). The cue utilization theory suggests that store image can be a determinant of product quality (Dawar and Parker, 1994). When customers are unaware about the brand the cues (product quality) can be determined from the store image. Therefore, store image can have a direct and positive relationship with consumer purchase intention.

\subsection{Purchase Intention}

Purchase intention is a behavioral action with the buying intention and possibility of purchase in response to a stimuli (Jin et al., 2016). It is also the willingness of customers to react to certain actions (Thakur and Srivastava, 2015). Pre-purchase behavior involves consumers gathering information regarding the product and retail store to evaluate their purchase decision (Wang et al., 2013).

The prospect theory is based on the study of nonrational consumption behavior in a rational way (Gefen et al., 2003). According to prospect theory the individual behavior is based on how individuals grade different alternatives, their expected results and possible risk perceptions. Consumers choose the alternative with maximum gain. The purpose of this theory is mentioned in terms of the attitude and drive for shopping that can affect consumer evaluation standard on their behavior. The theory has been widely used to explain the behavior of consumers (Camerer, 2011).

The theory of reasoned behavior states that when different consumer attitudes converge they form behavior (Sheppard et al., 1988). The theory also states that in the consumer decision making process the consumer attitude has a direct impact on the behavioral intention (Zhang and Kim, 2013). Researchers have discussed the process of recognizing the product that they want to buy; the next step is that they gather information regarding the product and evaluate the product. Lastly, they purchase the product and send feedback. So, before buying the product the shoppers gather significant information about the product they 
are intending to purchase so that their needs meet the demand. Purchase intention is stated as the possibility that buyers are willing to and able to purchase goods, an increase in purchase intention means that there is increased possibility that the shopper will buy the product. Purchase intention is also signaling behavior of consumers since an intention to buy represents positivity towards brand commitment (TEKIN et al., 2016). Purchase intention is also effected by a lot of external factors (Keller, 2001). These external factors can include variety of brands stocked in the store, physical location and timing (Das, 2014). The intrinsic factors include fulfillment of a need, preference satisfaction and placing the consumer in a better position (Luo et al., 2011).

$H_{1}$ : Store image has a significant and positive effect on purchase intention

\subsection{Learning Theory and Purchase Inten- tion}

Purchase Intention is influenced by the positive feelings associated with the brands carried by the retail store and external factors like store location, timing and brands sold by the store (Das, 2014). Intrinsic factors which affect purchase decision include fulfilling customer needs, satisfying customers and giving them an improved situation (Tang et al., 2011). Purchase intention can be used as a forecaster of consumer behavior suggested by Wu et al. (2011). Customers previous positive experience influences purchase intention (Kinard and Hartman, 2013). Learning theory suggests that to perform the purchase function consumers requires purchase and consumption knowledge for future repeat purchase (TEKIN et al., 2016). The two approaches to learning theory are behavioral and cognitive. The first one takes place because of the events happening in the external environment and reinforcement in learning. The second approach acknowledges the importance of the mental processes which play role in interpreting the environment and the past experiences with objects such as (brands etc). In this sense, store familiarity (Chebat et al., 2005; Diallo, 2012) and experienced based learning (Szymanowski and Gijsbrechts, 2013) play a crucial role in influencing purchase intention.

\subsection{Service Quality}

Service quality is the evaluation of the service provided by the service provider (Sharma et al., 2014). Service quality is based on five aspects touchable level, reliability, attentiveness, assurance and response (Rahman et al., 2012). The perceived service quality is based on the expectations and experiences (Jabnoun and Hassan Al-Tamimi, 2003). Service quality is a complex term for customers to measure than product or price as noted by Nakhai and Neves (2009). According to them, the perception of measuring service quality is to link customer expectation to the actual service performance. According to Chuang (2010) service quality can be estimated by measuring differences between perceptions and expectations about a service. There are two types of service quality concepts that exist; one is American, and one is European (Brady and Cronin Jr, 2001).

The American perspective focuses on the functional quality of service quality while the European perspective focuses on technical quality with image of service along with the functional element. Fullerton (2005) has adapted the scales from the study of Brady and Cronin Jr (2001) who identified three dimensions to evaluate the concept of service quality. The three dimensions are interaction quality, outcome quality and environment quality. Interaction quality is defined as the interaction between quality of service and between service providers and consumers. This dimension includes three indicators which are known as attitude behavior and expertise. Environment quality is basically the interaction of consumers with the overall evaluation of the environment and atmosphere. This dimension includes the ambiance of the retail outlet, the design and other social factors. Lastly, outcome quality is the total quality output received or experienced by the customer and is known as the total service outcome evaluation. This dimension consists of the valence factor, waiting time and tangibles.

According to various researchers it was found that perceived service quality by the consumers is a critical driver in the customer perception and behavior (Parasuraman and Grewal, 2000). Product quality, service quality and price are the major drivers of perceived value which in return determine customer loyalty. As explained earlier in the literature it has been discussed that the service quality was initially described as gap between the expectation and actual outcome while later it was criticized for the reliability and validity by Wang et al. (2004). To overcome this issue Dabholkar et al. (2000) came up with the concept of overall service quality which combined perceptions and expectations into a single term. Until recently the overall service quality has been used in studies. Dabholkar et al. (2000) suggested that the specific aspects of service quality have existed before, instead of components, of overall perceived quality.

$\mathrm{H}_{2}$ : Store image has a positive and significant effect on service quality.

$\mathrm{H}_{3}$ : Service quality as a positive and significant effect on purchase intention. 


\subsection{Relationship between Store Image, Purchase Intention and Service Quality}

Product quality is a key component of store image. Perceived product quality influences purchase intention (Wells et al., 2011). When a customer sees a product at a store, he takes an impression from the store and makes a perceived quality image in his mind. Product quality is also a determinant of repurchase intentions (Zhou et al., 2009). Store image can positively influence customers to buy products and services from the retail store and hence purchase intention (Bao et al., 2011; Diallo, 2012; Grewal et al., 1998; Wu et al., 2011).

Store image and service quality lead to customer satisfaction which affects the intention of customers to repurchase. Retail service quality aspects like the sales deals, wider product range and store atmosphere leads to customer satisfaction (Pan and Zinkhan, 2006). The in-store service quality complements the store image since the service encounters and the physical appearances \& behaviors have been rated highly by customers (Kim et al., 2012).

A direct and positive relationship between purchase intention and service quality has been found (Laroche et al., 2005; Mohan et al., 2013; Yap and Kew, 2007). Service quality has gained much importance by corporations since empirical studies investigated that service quality can help in improving the essential business objectives such as retaining customers and increasing productivity and profitability of firms (Carrillat et al., 2007; Kang and James, 2004; Ladhari, 2009). Also, service quality is viewed as the most difficult component to compete by competitors (Carlos Fandos Roig et al., 2006). Service quality enables value creation, value increases by increasing service quality while decreases with a decrease in service quality (Tam, 2012).

$\mathrm{H}_{4}$ : Service quality mediates the relationship between store image and purchase intention.

\subsection{Framework}

\section{Research Methodology}

\subsection{Sample}

The sample consisted of 265 customers of which 101 were males and 164 were females. The data were collected from the two stores Hyper star and Metro located in Lahore region. The respondents in the study included 94 employed,81 unemployed,64 full-time employed,11 part time employed and 15 others which majorly included retired people. The education level of the respondents varied from 4 who were matric, 31 had done intermediate, 135 were bachelors, 82 were masters and 13 acquired some other education.

\subsection{Measures}

\subsubsection{Purchase Intention}

Purchase Intention has been measured using the scale developed by Ha and Jang (2012) and Vijay (2013). Five-point Likert scales have been used to take responses from the customers which range from strongly agree (5) to strongly disagree (1). The items under purchase intention measured the likeliness of customers intending to purchase from the store again. The estimate for reliability was found to be 0.927 .

\subsubsection{Store Image}

Store image has been measured using the scale developed from the study by Dabholkar (1995) and Finn and Kayande (2004). Five-point Likert scales have been used in order to take responses from the customers which range from strongly agree (5) to strongly disagree (1). The items that measured store image included staff responsiveness, customer care, store atmosphere, shopping convenience and product assortment. The estimate for internal consistency was found to be 0.878 .

\subsubsection{Service Quality}

Service quality has been measured using 5 point likert the scale developed from the study by Dabholkar (1995) and Verma and Duggal (2015). The items measured under service quality included physical aspect, reliability, personal interaction, problem solving, policy and information on retailers. The estimate for internal consistency was found to be 0.947 .

\subsection{Procedure}

The survey was conducted with enough sample size making a strong basis to judge the impact of store image on purchase intention with mediating role of service quality. Quantitative approach has been used to and so self-administered questionnaires have been used to measure and validate the hypothesis. For the analysis purpose the processing tools used are SPSS (Version 22) and AMOS (Version 22) were used to perform analysis. The first phase involved data entry in SPSS. Data screening was done for finding outliers and missing values in SPSS. Descriptive statistics was used to spot any missing values and outliers in the data.

The next step involves checking reliability and validity of data.The reliability of factors was checked through the Cronbachs alpha value, Confirmatory Factor Analysis (CFA) and Structural equation model (SEM) have been used to examine the statistical ability and relation of the variables (Federici, 2013)]. Structural Equation Model (SEM) is a statistical tool that uses 


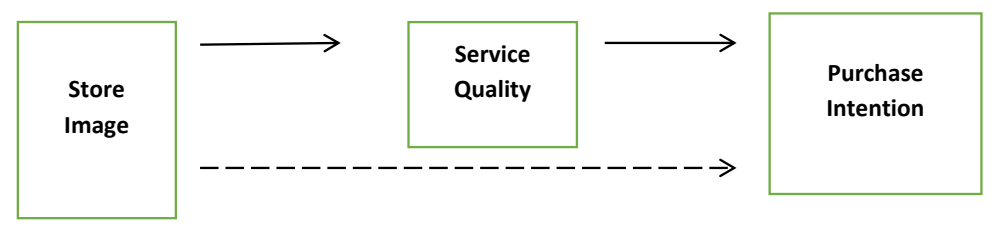

Figure 1: Research Framework

factor analysis and path analysis (Qureshi and Compeau, 2009). SEM is used because its a more reliable statistical technique to analyze data with flexible assumptions and minimal chances of error.

\section{Results}

To measure the model a twostep approach has been incorporated. CFA approach has been used to test the model (Hair et al., 2011).

As a rule, the measurement model is tested before the structural equation model (Anderson and Gerbing, 1988; Sengars and Grover, 1993). Reliability is a measure to assess the internal consistency of the questionnaire (Sekaran and Bougie, 2016). While validity confirms that each item under the construct is actually able to measure the construct. Reliability and validity can be analyzed by Cronbachs Alpha value, factor loadings and the value of AVE and CR (composite reliability) (Carlson and Herdman, 2012).

The above table shows that the Cronbachs alpha value ranges from 0.877 to 0.934 , the minimum acceptable value according to Hair et al. (2011) is 0.5.The value of AVE ranges between 0.513 to 0.616 ,all the values fulfill the minimum requirement of 0.5 (Hong and Cha, 2013). The composite reliability which is a measure of internal consistency ranges from 0.878 to 0.947 , each item meets the minimum acceptable value of 0.6 (Fornell, 1982). The value of MSV should always be less than AVE, it measures the level to which a variable can be explained in terms of other variable (Farrell and Rudd, 2009).

\subsection{Goodness of Fit}

The maximum likelihood estimation method has been used to analyze estimates for the model (Chang and Tseng, 2013).

The above table shows the maximum likelihood estimation (Chang and Tseng, 2013). All the values in the acceptable range indicate that the model has an acquired model fit. The Chi-square value of 2.421 is acceptable which is below the acceptable value of 3.This value helps in evaluating the model by minimizing the effect of sample size on the model fit (Byrne, 2016). The value of GFI is 0.823 which is greater than the suggested value of 0.8.It is a goodness of fit statistic and indicates the variance which is accounted by the population co-variance (Tabachnick et al., 2007). The value of AGFI which helps to adjust the GFI on the basis of degrees of freedom is below the suggested value of 0.8 and is 0.776. Research suggests that since the values of GFI and AGFI are influenced by the sample size and the degrees of freedom it is difficult to determine the suggested or appropriate values of GFI and AGFI from the perspective of power analysis (MacCallum and Hong, 1997). The value of TLI should be greater than 0.9 and for our model it is 0.889 .TLI also adjusts the model on the degrees of freedom (Fornell, 1982). CFI is based on the assumption that all the variables are uncorrelated and on this basis it compares the sample co-variance matrix with the null model (Fornell, 1982). The value of CFI is 0.906 above the acceptable value of 0.9.RMSEA indicates the wellness of model, the value of RMSEA is below the minimum value of 0.08 for the model it is 0.073 which indicates model fitness.

\subsection{Structural Equation Model and Hy- pothesis Testing}

Hypothesis was tested through structural equation model. The results of the SEM did not confirm model fit purely based on our data but of other indices based on the (incremental fit) our model fits the data perfectly, i.e., (chi-square $=2.421$, GFI $=0.823$, AGFI $=0.776$, $\mathrm{TLI}=0.889, \mathrm{CFI}=0.906$, RMSEA=0.073). The results show that the independent variable store image has a significant effect on the dependent variable purchase intention and mediator service quality with a p-value less than 0.001 . Therefore, hypothesis $\mathrm{H}_{1}$ (Store Image $\rightarrow$ Purchase Intention)and $\mathrm{H}_{2}$ (Store Image $\rightarrow$ Service Quality) are supported (Awang, 2012).This thus supports the argument that customers tend to buy more , their intention to purchase increases with an attractive image, quality merchandize and a comfortable shopping environment and this also effects the quality of service positively. With reference to $\mathrm{H}_{3}$ (Service Quality $\rightarrow$ Purchase Intention), the ratios (S.E $=0.038$, C.R=7.532, $\mathrm{p}<0.001$ ) support the hypothesis.

\subsection{Mediation Analysis}

The purpose of this section of analysis is to determine the mediation hypothesis. According to Baron 
Table 1: Item reliability, composite reliability and average variance extracted

\begin{tabular}{lccccc}
\hline Variables & Items & Cronbach's alpha & AVE & CR & MSV \\
\hline Store Image & SII & 0.889 & 0.616 & 0.927 & 0.188 \\
Purchase Intention & PII & 0.877 & 0.595 & 0.878 & 0.224 \\
Service Quality & SQQ & 0.934 & 0.513 & 0.947 & 0.224 \\
\hline
\end{tabular}

Table 2: Model Fit Summary

\begin{tabular}{lcc}
\hline Measures & Recommended Criteria & Model Fit \\
\hline CMIN/DF & $<3$ & 2.421 \\
GFI & $>0.8$ & 0.823 \\
AGFI & $>0.8$ & 0.776 \\
TLI & $>0.9$ & 0.889 \\
CFI & $>0.9$ & 0.906 \\
RMSEA & $<0.08$ & 0.073 \\
\hline
\end{tabular}

Table 3: Structural Model Results

\begin{tabular}{lcccc}
\hline Structural Path (Standardized Regression Weight) & Estimate & S.E & C.R & P \\
\hline $\mathbf{H}_{1}$ Store Image $\rightarrow$ Purchase Intention & 0.209 & 0.03 & 6.883 & $* * *$ \\
$\mathbf{H}_{2}$ Store Image $\rightarrow$ Service Quality & 0.228 & 0.047 & 4.864 & $* * *$ \\
$\mathbf{H}_{3}$ Service Quality $\rightarrow$ Purchase Intention & 0.288 & 0.038 & 7.532 & $* * *$ \\
\hline Note $^{*}=p<0.05,{ }^{* *}=p<0.01,{ }^{* * *}=p<0.001$ & & &
\end{tabular}

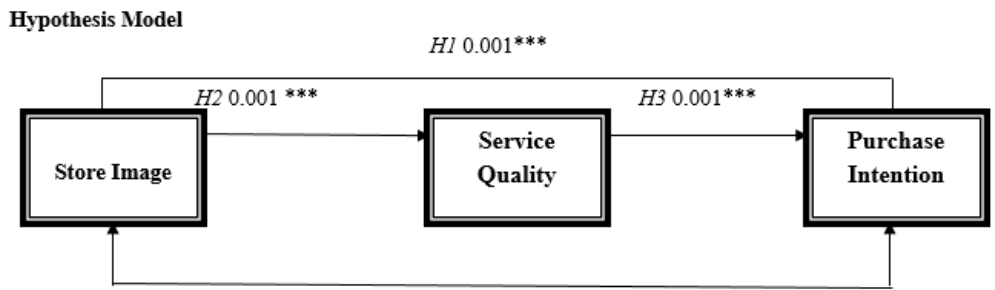

Figure 2: Hypothesis Model

and Kenny (1986), there are three levels of mediation that is full, partial and no mediation.

The statistical significance test for mediation is done through the bootstrapping technique with a sample size of 2000 (Shrout and Bolger, 2002). For the current study this sample size is used for measuring direct and indirect effects of (store image, purchase intention and service quality).

The above table shows the direct and indirect effects. The results presented in the above table explain service quality partially mediates the relationship between store image and purchase intention by fulfilling the direct and indirect path effect. This is also proven by the significant effect of store image on purchase intention with values $(p<0.001, \beta=0.355)$,store image on service quality $(\mathrm{p}<0.001, \beta=0.287)$ and service quality on purchase intention $(\mathrm{p}<0.001, \beta=0.388)$. An insignificant effect is shown by ( $p>0.05, \beta=0.111)$ with the stan- dardized two-tail significance being significant which hence proves partial mediation is caused by service quality.

\section{Discussion}

The study was conducted from the perspective of two international retail stores operating in Pakistan. As its evident from the presence of and opening of large malls and hypermarkets in Pakistan, a change in the shopping trend has been observed. Many studies have been conducted with the perspective of store brands or a brand name, but store image of large entities have not been fully explored.

The first hypothesis $\mathrm{H} 1$ is that store image positively effects purchase intention. A strong and positive relationship has been found between store image and 
Table 4: Direct and Indirect Effect

\begin{tabular}{|c|c|c|}
\hline \multicolumn{3}{|l|}{ Direct Effects } \\
\hline & Standardized & Unstandardized \\
\hline $\mathrm{SI} \rightarrow \mathrm{PI}$ & $0.355^{* * *}$ & $0.209^{* * *}$ \\
\hline $\mathrm{SI} \rightarrow \mathrm{SQ}$ & $0.287^{* * *}$ & $0.228^{* * *}$ \\
\hline $\mathrm{SQ} \rightarrow \mathrm{PI}$ & $0.388^{* * *}$ & $0.288^{* * *}$ \\
\hline \multicolumn{3}{|l|}{ Indirect Effects } \\
\hline $\mathrm{SI} \rightarrow \mathrm{SQ} \rightarrow \mathrm{PI}$ & 0.111 & 0.066 \\
\hline Two-tailed significance & 0.001 & \\
\hline
\end{tabular}

purchase intention, since the perceptions of store image play an important role in building perception in consumers minds which then creates image whereas purchase intention is the reflection of the consumers idea of store image in their minds. It has been stated that consumers will purchase more if there is positive store image (Collins-Dodd and Lindley, 2003; Diallo, 2012).

The next hypothesis is that store image has a positive relationship with service quality. This is also supported by the existing literature. Store image has been described as a complex combination of dimensions which are build up from consumers past shopping experiences (Weber Cullen et al., 2002).

The third hypothesis is that service quality has a significant positive impact on purchase intention. The hypothesis was derived from the existing literature in field. Service quality is defined as the extent to which a customer is satisfied from availing the services. Consumer purchase intention is the desire to buy a product or service (Diallo, 2012). Direct relationship has been found between image of a store and purchase intention, also applicable in case of private store brands. It has been stated that when store image is positive the chances of purchase increases automatically (CollinsDodd and Lindley, 2003; Diallo, 2012). Although, service quality has not been measured as a mediator between store image and purchase intention, but our research concludes from the statistical analysis that service quality partially mediates between store image and purchase intention and hence our fourth hypothesis $\mathrm{H} 4$ is also accepted based on the statistical results.

\subsection{Limitations, Conclusion and Recom- mendations}

The research has some limitations. Firstly, it was only conducted in the Lahore region (Pakistan) with two retailers (Hyper star and Metro). For study with a broader perspective other region with these two retailers could have been included for more generalized results. Secondly, one of the restrictions was time otherwise its a better option to go for longitudinal research since it covers a broader time frame and it studies the cause and effect relationship between variables more thoroughly (Ryder et al., 2006). Thirdly ,store image is built up of a number of factors which can effect purchase intention and likewise service quality has several dimensions, the dimensions of each of these variables were chosen based on the study of the two retail stores with respect to our culture, since both the retail stores are international study could have been conducted across cultures to get a wider and clearer picture of the variable effects and interrelationships. Lastly, for better research results a combination of qualitative and quantitative research could have been used for the study.

\subsection{Future Directions}

Since this research is an initial effort as a research student, further inquiry into the subject is required, for example other dimensions of store image and service quality can be included in the study. An, overall study was conducted to evaluate the effect of store image on purchase intention, the subject of research was wide and general, future researchers can restrict research for example specify to departments like grocery, furniture, electronics for more specified and accurate results this can help researchers to go in depth of the research issue. From the perspective of store image and purchase intention, online purchases can also be focused since many modern retailers are offering online and home delivery services. Also, more than one independent variable can be added to study the effect on purchase intention for example store loyalty and store image could both contribute effect on purchase intention. Future research could also target psychographics and demographics of customers, segmentation of customers would give more accurate results and basis for analysis. Longitudinal research should be used by future researchers this would help them to get a wide range of results with broader perspective and the cause and effect relationship can be understood more effectively. A comparative study should be done between two or more cities; this would give a broader perspective. 
A mixed method of research can be used for future research that would include both quantitative and qualitative research. Retailer perspective should also be entertained, and data collection should be done with the customer and retailer perspective.

\subsection{Implications}

The marketing managers utilize the results obtained from the research to make critical marketing decisions. The study indicates that store image has a significant effect on service quality and purchase intention. Therefore, managers can make the perception of stores better by enhancing the service provided to customers. For instance, the management staff can improve the quality of interaction between the staff and the customers. The store environment can be improved and made more attractive to attract customers. Other atmospherics can be focused like the kind of music played at the retail store, in-store facilities, layout of store etc.

Store image can also be improved by improving the variety of products, the product quality, product offerings, improving the ambiance of the store, making the store more attractive with physical facilities. The research can provide guideline for the marketing managers of the stores to device their marketing strategy and thus improve the target customers with affecting the purchase intention through improvements in the store image and service quality provided by both $\mathrm{Hy}-$ per star and Metro.

\subsection{Conclusion}

The research conducted reveals the factors which can influence the customers intention to purchase in two international retail stores Hyper star and Metro operating in Pakistan. The research has given some useful insights that marketing managers may have overlooked while strategizing their marketing plans. The conventional criteria of marketing managers that was product, price, promotion and placement have now been replaced by other influential factors like interaction, store atmospherics, store image building and these factors have been proven substantial in enhancing customers purchase intention.

The study has proven that store image which includes staff responsiveness, customer care, store atmosphere, product assortment and shopping convenience play an important role in affecting purchase intention (TEKİN et al., 2016). The practical implications of this research can be very useful for people involved in hypermarket business and those who want to enter the retail business.

\section{References}

Ailawadi, K. L. and Keller, K. L. (2004). Understanding retail branding: conceptual insights and research priorities. Journal of retailing, 80(4):331-342.

Anderson, J. C. and Gerbing, D. W. (1988). Structural equation modeling in practice: A review and recommended two-step approach. Psychological bulletin, 103(3):411.

Arnould, E. J. and Thompson, C. J. (2005). Consumer culture theory (cct): Twenty years of research. Journal of consumer research, 31(4):868-882.

Bao, Y., Bao, Y., and Sheng, S. (2011). Motivating purchase of private brands: Effects of store image, product signatureness, and quality variation. Journal of Business Research, 64(2):220-226.

Baron, R. M. and Kenny, D. A. (1986). The moderatormediator variable distinction in social psychological research: Conceptual, strategic, and statistical considerations. Journal of personality and social psychology, 51(6):1173.

Batislam, E. and Filiztekin, A. (2011). Channel switching behavior during the modernization of grocery retailing in turkey.

Bloemer, J., Brijs, T., Swinnen, G., and Vanhoof, K. (2002). Identifying latently dissatisfied customers and measures for dissatisfaction management. International Journal of Bank Marketing, 20(1):27-37.

Brady, M. K. and Cronin Jr, J. J. (2001). Some new thoughts on conceptualizing perceived service quality: a hierarchical approach. Journal of marketing, 65(3):34-49.

Byrne, B. M. (2016). Structural equation modeling with AMOS: Basic concepts, applications, and programming. Routledge.

Camerer, C. F. (2011). Behavioral game theory: Experiments in strategic interaction. Princeton University Press.

Carlos Fandos Roig, J., Sanchez Garcia, J., Angel Moliner Tena, M., and Llorens Monzonis, J. (2006). Customer perceived value in banking services. International Journal of Bank Marketing, 24(5):266-283.

Carlson, K. D. and Herdman, A. O. (2012). Understanding the impact of convergent validity on research results. Organizational Research Methods, 15(1):17-32.

Carrillat, F. A., Jaramillo, F., and Mulki, J. P. (2007). The validity of the servqual and servperf scales: A meta-analytic view of 17 years of research across five continents. International Journal of Service Industry Management, 18(5):472-490.

Chang, E.-C. and Tseng, Y.-F. (2013). Research note: E-store image, perceived value and perceived risk. Journal of business research, 66(7):864-870.

Chebat, J.-C., Gélinas-Chebat, C., and Therrien, K. (2005). Lost in a mall, the effects of gender, familiarity with the shopping mall and the shopping values on shoppers' wayfinding processes. Journal of Business Research, 58(11):1590-1598. 
Chuang, P.-T. (2010). Incorporating disservice analysis to enhance perceived service quality. Industrial Management $\mathcal{E}$ Data Systems, 110(3):368-391.

Collins-Dodd, C. and Lindley, T. (2003). Store brands and retail differentiation: the influence of store image and store brand attitude on store own brand perceptions. Journal of Retailing and consumer services, 10(6):345-352.

Dabholkar, P. A. (1995). A contingency framework for predicting causality between customer satisfaction and service quality. ACR North American Advances.

Dabholkar, P. A., Shepherd, C. D., and Thorpe, D. I. (2000). A comprehensive framework for service quality: an investigation of critical conceptual and measurement issues through a longitudinal study. Journal of retailing, 76(2):139173.

Das, G. (2014). Linkages of retailer personality, perceived quality and purchase intention with retailer loyalty: A study of indian non-food retailing. Journal of Retailing and Consumer Services, 21(3):407-414.

Davis, L., Wang, S., and Lindridge, A. (2008). Culture influences on emotional responses to on-line store atmospheric cues. Journal of Business Research, 61(8):806-812.

Dawar, N. and Parker, P. (1994). Marketing universals: consumers use of brand name, price, physical appearance, and retailer reputation as signals of product quality. Journal of marketing, 58(2):81-95.

Dhar, S. K. and Hoch, S. J. (1997). Why store brand penetration varies by retailer. Marketing Science, 16(3):208-227.

Diallo, M. F. (2012). Effects of store image and store brand price-image on store brand purchase intention: Application to an emerging market. Journal of Retailing and Consumer Services, 19(3):360-367.

Dolbec, P.-Y. and Chebat, J.-C. (2013). The impact of a flagship vs. a brand store on brand attitude, brand attachment and brand equity. Journal of Retailing, 89(4):460-466.

Farrell, A. M. and Rudd, J. M. (2009). Factor analysis and discriminant validity: A brief review of some practical issues. Anzmac.

Federici, R. A. (2013). Principals self-efficacy: Relations with job autonomy, job satisfaction, and contextual constraints. European journal of psychology of education, 28(1):73-86.

Finn, A. and Kayande, U. (2004). Scale modification: alternative approaches and their consequences. Journal of Retailing, 80(1):37-52.

Fornell, C. (1982). A second generation of multivariate analysis. 2. Measurement and evaluation, volume 2. Praeger Publishers.

Fullerton, G. (2005). The impact of brand commitment on loyalty to retail service brands. Canadian Journal of Administrative Sciences/Revue Canadienne des Sciences de l'Administration, 22(2):97-110.
Gefen, D., Karahanna, E., and Straub, D. W. (2003). Trust and tam in online shopping: an integrated model. MIS quarterly, 27(1):51-90.

González, M. E. A., Comesaña, L. R., and Brea, J. A. F. (2007). Assessing tourist behavioral intentions through perceived service quality and customer satisfaction. Journal of business research, 60(2):153-160.

Grewal, D., Krishnan, R., Baker, J., and Borin, N. (1998). The effect of store name, brand name and price discounts on consumers' evaluations and purchase intentions. Journal of retailing, 74(3):331-352.

Ha, J. and Jang, S. (2012). The effects of dining atmospherics on behavioral intentions through quality perception. Journal of Services Marketing, 26(3):204-215.

Hair, J. F., Ringle, C. M., and Sarstedt, M. (2011). Pls-sem: Indeed a silver bullet. Journal of Marketing theory and Practice, 19(2):139-152.

Hartman, K. B. and Spiro, R. L. (2005). Recapturing store image in customer-based store equity: a construct conceptualization. Journal of Business research, 58(8):1112-1120.

Herz, M. F. and Diamantopoulos, A. (2013). Activation of country stereotypes: automaticity, consonance, and impact. Journal of the Academy of Marketing Science, 41(4):400417.

Hong, I. B. and Cha, H. S. (2013). The mediating role of consumer trust in an online merchant in predicting purchase intention. International Journal of Information Management, 33(6):927-939.

Jabnoun, N. and Hassan Al-Tamimi, H. A. (2003). Measuring perceived service quality at uae commercial banks. International Journal of Quality \& Reliability Management, 20(4):458472.

Jaliawala, M. M. et al. (2014). Channel switching behavior from traditional grocery stores to branded grocery chains in karachi. Journal of Independent Studies \& Research: Management $\mathcal{E}$ Social Sciences E Economics, 12(2).

Jin, B., Almousa, M., Yang, H., Kim, N., and Gil, M. (2016). Asymmetrical roles of macro and micro country images on saudi consumers' purchase intention.

Kang, G.-D. and James, J. (2004). Service quality dimensions: an examination of grönrooss service quality model. Managing Service Quality: An International Journal, 14(4):266277.

Kaul, S. (2005). Impact of performance and expressiveness value of store service quality on the mediating role of satisfaction.

Keller, K. L. (2001). Building customer-based brand equity: A blueprint for creating strong brands. Marketing Science Institute Cambridge, MA.

Kim, C., Galliers, R. D., Shin, N., Ryoo, J.-H., and Kim, J. (2012). Factors influencing internet shopping value and customer repurchase intention. Electronic Commerce Research and Applications, 11(4):374-387. 
Kinard, B. R. and Hartman, K. B. (2013). Are you entertained? the impact of brand integration and brand experience in television-related advergames. Journal of Advertising, 42(23):196-203.

Ladhari, R. (2009). Service quality, emotional satisfaction, and behavioural intentions: A study in the hotel industry. Managing Service Quality: An International Journal, 19(3):308331.

Laroche, M., Teng, L., Michon, R., and Chebat, J.-C. (2005). Incorporating service quality into consumer mall shopping decision making: a comparison between english and french canadian consumers. Journal of Services Marketing, 19(3):157-163.

Luo, M. M., Chen, J.-S., Ching, R. K., and Liu, C.-C. (2011). An examination of the effects of virtual experiential marketing on online customer intentions and loyalty. The Service Industries Journal, 31(13):2163-2191.

MacCallum, R. C. and Hong, S. (1997). Power analysis in covariance structure modeling using gfi and agfi. Multivariate Behavioral Research, 32(2):193-210.

Moazzam, M. and Badar, H. (2006). Drivers of superstore shopping: A case study of faisalabad city. Pakistan Journal of Life and Social Sciences, 4(1-2):76-80.

Mohan, G., Sivakumaran, B., and Sharma, P. (2013). Impact of store environment on impulse buying behavior. European Journal of marketing, 47(10):1711-1732.

Nakhai, B. and Neves, J. S. (2009). The challenges of six sigma in improving service quality. International Journal of Quality $\mathcal{E}$ Reliability Management, 26(7):663-684.

Pan, Y. and Zinkhan, G. M. (2006). Determinants of retail patronage: a meta-analytical perspective. Journal of retailing, 82(3):229-243.

Parasuraman, A. and Grewal, D. (2000). The impact of technology on the quality-value-loyalty chain: a research agenda. Journal of the academy of marketing science, 28(1):168-174.

Pettijohn, L. S., Mellott, D. W., and Pettijohn, C. E. (1992). The relationship between retailer image and brand image. Psychology \& Marketing, 9(4):311-328.

Priporas, C. V. A. (2002). Store image and customer satisfaction. PhD thesis, Newcastle University.

Qureshi, I. and Compeau, D. (2009). Assessing betweengroup differences in information systems research: a comparison of covariance-and component-based sem. Mis Quarterly, pages 197-214.

Rahman, M. S., Khan, A. H., and Haque, M. M. (2012). A conceptual study on the relationship between service quality towards customer satisfaction: Servqual and gronroos's service quality model perspective. Asian Social Science, 8(13):201.
Ryder, R. J., Burton, J. L., and Silberg, A. (2006). Longitudinal study of direct instruction effects from first through third grades. The Journal of Educational Research, 99(3):179-192.

Šalčiuvienė, L., Auruškevičienè, V., and Lee, K. (2009). The effect of personal values on customer loyalty. Transformations in Business E Economics, 8(1).

Sekaran, U. and Bougie, R. (2016). Research methods for business: A skill building approach. John Wiley \& Sons.

Sengars, A. and Grover, V. (1993). Re-examining perceived ease of use and usefulness: A confirmatory factor analysis. Management Information Systems Quarterly, 17(4):7.

Sharma, P., Kim, W., Lee, J. G., Lee, S.-J., and Tourrilhes, J. (2014). Dynamic balancing priority queue assignments for quality-of-service network flows. US Patent 8,670,310.

Sheppard, B. H., Hartwick, J., and Warshaw, P. R. (1988). The theory of reasoned action: A meta-analysis of past research with recommendations for modifications and future research. Journal of consumer research, 15(3):325-343.

Shrout, P. E. and Bolger, N. (2002). Mediation in experimental and nonexperimental studies: new procedures and recommendations. Psychological methods, 7(4):422.

Sprott, D. E. and Shimp, T. A. (2004). Using product sampling to augment the perceived quality of store brands. Journal of Retailing, 80(4):305-315.

Szymanowski, M. and Gijsbrechts, E. (2013). Patterns in consumption-based learning about brand quality for consumer packaged goods. International Journal of Research in Marketing, 30(3):219-235.

Tabachnick, B. G., Fidell, L. S., and Ullman, J. B. (2007). Using multivariate statistics, volume 5. Pearson Boston, MA.

Tam, J. L. (2012). Linking perceived service quality to relational outcomes in a chinese context. Journal of International Consumer Marketing, 24(1-2):7-23.

Tang, Z., Luo, J., and Xiao, J. (2011). Antecedents of intention to purchase mass customized products. Journal of Product $\mathcal{E}$ Brand Management, 20(4):316-326.

TEKİN, G., YILTAY, S., and Esra, A. (2016). The effect of brand image on consumer behaviour: Case study of louiss vuitton-moet hennessy. International Journal of Academic Values Studies, (2):1-24.

Thakur, R. and Srivastava, M. (2015). A study on the impact of consumer risk perception and innovativeness on online shopping in india. International Journal of Retail $\mathcal{E}$ Distribution Management, 43(2):148-166.

Theodoridis, P. K. and Chatzipanagiotou, K. C. (2009). Store image attributes and customer satisfaction across different customer profiles within the supermarket sector in greece. European Journal of Marketing, 43(5/6):708-734.

Vahie, A. and Paswan, A. (2006). Private label brand image: its relationship with store image and national brand. International Journal of Retail $\mathcal{E}$ Distribution Management, 34(1):67-84. 
Verhoef, P. C., Lemon, K. N., Parasuraman, A., Roggeveen, A., Tsiros, M., and Schlesinger, L. A. (2009). Customer experience creation: Determinants, dynamics and management strategies. Journal of retailing, 85(1):31-41.

Verma, H. V. and Duggal, E. (2015). Retail service quality in india: construct exploration and measure development. South Asian Journal of Global Business Research, 4(1):129-148.

Vijay, S. A. (2013). Work-related musculoskeletal health disorders among the information technology professionals in india: A prevalence study. Int J Mgmt Res Bus Strat, 2(2):118-28.

Wang, J.-S., Cheng, Y.-F., and Chu, Y.-L. (2013). Effect of celebrity endorsements on consumer purchase intentions: advertising effect and advertising appeal as mediators. Human Factors and Ergonomics in Manufacturing $\mathcal{E}$ Service Industries, 23(5):357-367.

Wang, Y., Lo, H.-P., and Yang, Y. (2004). An integrated framework for service quality, customer value, satisfaction: Evidence from china's telecommunication industry. Information systems frontiers, 6(4):325-340.

Weber Cullen, K., Baranowski, T., Owens, E., De Moor, C., Rittenberry, L., Olvera, N., and Resnicow, K. (2002). Ethnic differences in social correlates of diet. Health education research, 17(1):7-18.

Wells, J. D., Valacich, J. S., and Hess, T. J. (2011). What signal are you sending? how website quality influences per- ceptions of product quality and purchase intentions. MIS quarterly, pages 373-396.

Woodside, A. G. (2012). Consumer evaluations of competing brands: Perceptual versus predictive validity. Psychology $\mathcal{E}$ Marketing, 29(6):458-466.

Wu, P. C., Yeh, G. Y.-Y., and Hsiao, C.-R. (2011). The effect of store image and service quality on brand image and purchase intention for private label brands. Australasian Marketing Journal (AMJ), 19(1):30-39.

Yap, S. F. and Kew, M. L. (2007). Service quality and customer satisfaction: antecedents of customer's re-patronage intentions. Sunway Academic Journal, 4:59-73.

Yaprak, A. (2008). Culture study in international marketing: a critical review and suggestions for future research. International Marketing Review, 25(2):215-229.

Zhang, B. and Kim, J.-H. (2013). Luxury fashion consumption in china: Factors affecting attitude and purchase intent. Journal of Retailing and Consumer Services, 20(1):68-79.

Zhang, J. (2009). The effect of advertising appeals in activating self-construals: A case of bicultural chinese generation x consumers. Journal of Advertising, 38(1):63-82.

Zhou, T., Lu, Y., and Wang, B. (2009). The relative importance of website design quality and service quality in determining consumers online repurchase behavior. Information Systems Management, 26(4):327-337. 